\title{
Las especies silvestres de Phaseolus (Fabaceae) en Nuevo León, México*
}

\author{
The wild species of Phaseolus (Fabaceae) \\ in Nuevo León, Mexico
}

\begin{abstract}
Efraín Acosta-Díaz ${ }^{1 \S}$, Ismael Hernández-Torres ${ }^{1}$, Mario Domingo Amador-Ramírez ${ }^{2}$, José Saúl Padilla-Ramírez ${ }^{3}$ y Francisco Zavala-García ${ }^{4}$

'Campo Experimental General Terán-INIFAP.Carretera Montemorelos-China,km31.General Terán, Nuevo León. C.P.67400.(acosta.efrain@inifap.gob.mx; hernandez. ismael @inifap.gob.mx). ${ }^{2}$ Campo Experimental Zacatecas, INIFAP. Carretera Zacatecas-Fresnillo, km 24.5. Calera de Víctor Rosales, Zacatecas. C. P. 98500. C. P. 18. (castor_aztlan@hotmail.com). ${ }^{3}$ Campo Experimental Pabellón-INIFAP. (padilla.saul@inifap.gob.mx). ${ }^{4}$ Universidad Autónoma de Nuevo León. Facultad deAgronomía. Área deEstudios de Posgrado, carretera Zuazua-Marín,km 17.5, Marín N.L., México.(francisco.zavala.garcia@gmail.com). ${ }^{\S}$ Autor para correspondencia: acostaefrain@ yahoo.com.mx.
\end{abstract}

\section{Resumen}

La región de la Sierra Madre Oriental, aunque reconocida por su diversidad de especies silvestres del género Phaseolus (Fabaceae), ha sido explorada en forma parcial y no siempre en forma sistemática; además, en el banco de germoplasma del INIFAP no existen muestras de semilla para su caracterización y conservación ex situ. Con base en lo anterior, y la creciente reducción de la variabilidad genética por causas antropocéntricas, se decidió realizar exploración y recolección de especies de Phaseolus silvestres. El objetivo del presente trabajo fue documentar la recolecta de poblaciones silvestres de frijol en la región de la Sierra Madre Oriental en Nuevo León. Entre 2010y 2012 se realizó una intensa exploración en 12 municipios de Nuevo León. Se localizaron e identificaron siete especies (Phaseolus neglectus, $P$. leptostachyus, P. pedicellatus, P. albiflorus, P. novoleonensis, $P$. maculatifolius y $P$. zimapanensis) y se recolectaron 54 muestras de semillas, en donde la mayoría provino de los municipios de Santiago (20\%), Aramberri (19\%) y Rayones (15\%); mientras que $46 \%$ se obtuvo en otros municipios. El germoplasma recolectado se conservó ex situ en el banco de germoplasma de la Universidad Autónoma Agraria Antonio Narro. Sin embargo, existen

\section{Abstract}

The Sierra Madre Oriental region, although known for its diversity of wild species of the genus Phaseolus (Fabaceae) has been partially and not always systematically explored, moreover, in the INIFAP germplasm bank there are no seed samples for characterization and ex situ conservation. Based on the above and the increasing reduction of genetic variability by anthropocentric causes, it was decided to carry out exploration and collection of wild species of Phaseolus. The aim of this study was to document the collection of wild bean populations in the Sierra Madre Oriental region in Nuevo León. Between 2010 and 2012 an intense exploration was carried out in 12 municipalities of Nuevo León. Seven species were located and identified (Phaseolus neglectus, P. leptostachyus, $P$. pedicellatus, $P$. albiflorus, $P$. novoleonensis, $P$. maculatifolius and $P$. zimapanensis) and 54 seed samples were collected, most came from the Santiago (20\%), Aramberri (19\%) and Rayones (15\%) municipalities; while $46 \%$ was obtained in other municipalities. The collected germplasm was ex situ preserved in the germplasm bank of the Antonio Narro Autonomous Agricultural University. However, previously reported

\footnotetext{
* Recibido: febrero de 2014

Aceptado: marzo de 2014
} 
probabilidades de que se hayan perdido, a través de los años, especies que habían sido reportadas anterioriormente, por lo que es necesario continuar las recolectas en Nuevo León, así como en otros estados de la región.

Palabras clave: Phaseolus spp., especies silvestres, recursos genéticos, Nuevo León.

\section{Introducción}

México, por su posición geográfica en el Continente Americano, por su variada topografía y su diversidad climática, alberga una amplia diversidad biológica, y está considerado como el principal centro de diversidad del género Phaseolus (Gepts et al., 1986; Gepts y Debouck, 1991), en donde la mayoría de las especies silvestres de este género crecen y algunas son endémicas (Delgado Salinas, 1985; Delgado Salinas et al., 1988; Delgado Salinas et al., 2006; Delgado Salinas, 2012; Freytag y Debouck, 2002). En la segunda mitad del siglo pasado se realizaron grandes esfuerzos en recolectar, conservar y utilizar los recursos fitogenéticos; como resultado, la variabilidad genética de las formas cultivadas de frijol está bien representada en los bancos de germoplasma, no así la de sus parientes silvestres, los que no exceden 10\% del total de accesiones (Cárdenas Ramos et al., 1996).

El género Phaseolus comprende 75 taxones, la mayoría son formas silvestres que están distribuidas en todas las regiones fisiográficas de México (Freytag y Debouck, 2002; Peña Valdivia et al., 2012).

La región de la Sierra Madre Oriental en Nuevo León está reconocida por su diversidad de especies silvestres de Phaseolus (McVaugh, 1987; Freytag y Debouck, 2002), en donde se han recolectado varias accesiones de frijoles silvestres (Rodríguez Cabrera et al., 1985; Estrada Castillón et al., 2004); recientemente se describió P.novoleonensis como una especie nueva (Salcedo et al., 2006). Sin embargo, en el Catálogo del Banco de Germoplasma de Phaseolus del Instituto Nacional de Investigaciones Forestales, Agrícolas y Pecuarias (INIFAP), no se reportan muestras de semilla (Cárdenas et al., 1996; Freytag y Debouck, 2002), lo cual ha detenido el estudio de diversas especies (Acosta-Gallegos et al., 1996); además, cuando se cuenta con semilla suficiente, su acceso es muy difícil (Acosta-Gallegos et al., 2007). species are likely to be lost over the years, therefore there is a need to continue the collections in Nuevo León, and other states in the region.

Keywords: Phaseolus spp., wild species, genetic resources, Nuevo León.

\section{Introduction}

Mexico, given its geographical position in the Americas, its varied topography and climatic diversity, hosts a wide biodiversity, and is regarded as the major center of diversity of the genus Phaseolus (Gepts et al., 1986; Gepts and Debouck, 1991), where most of the wild species of this genus grow and some are endemic (Delgado Salinas, 1985; Delgado Salinas et al., 1988; Delgado Salinas et al., 2006; Freytag and Debouck, 2002; Delgado Salinas, 2012). In the second half of the last century great efforts were made to collect, preserve and use plant genetic resources, as a result, the genetic variability of the cultivated forms of beans is well represented in germplasm banks, but not that of their wild relatives, which do not exceed $10 \%$ of the total accessions (Cárdenas Ramos et al., 1996). The genus Phaseolus comprises 75 taxa, most are wild forms distributed in all physiographic regions of Mexico (Freytag y Debouck, 2002; Peña Valdivia et al., 2012).

The Sierra Madre Oriental region in Nuevo León is known for its diversity of wild species of Phaseolus (McVaugh, 1987; Freytag and Debouck, 2002), where several accessions of wild beans have been collected (Rodríguez Cabrera et al., 1985; Estrada Castillón et al., 2004); P. novoleonensis was recently described as a new species (Salcedo et al., 2006). However, in the Phaseolus Catalogue of the Germplasm Bank at the National Institute of Forestry, Agriculture and Livestock(INIFAP), no seed samples are reported (Cárdenas et al., 1996; Freytag and Debouck, 2002), which has stopped the study of various species (Acosta-Gallegos et al., 1996); also when enough seed is available, the access is very difficult (Acosta-Gallegos et al., 2007).

Based on the above, the present work was carried out to collect seed samples of wild bean germplasm in Nuevo León, for preservation and future use in different lines of research. 
Con base en lo anterior, se realizó el presente trabajo con el objetivo de realizar una recolecta de muestras de semillas de germoplasma silvestre de frijol en Nuevo León, para su conservación y futuro aprovechamiento en diferentes líneas de investigación.

La recolecta se realizó en 12 municipios del estado de Nuevo León con antecedentes importantes en diversidad de especies de Phaseolus silvestre correspondientes a la región de $\mathrm{La}$ Sierra Madre Oriental de México, localizada geográficamente entre $23^{\circ} 56^{\prime} 23^{\prime \prime}$ y $25^{\circ} 42^{\prime} 59^{\prime \prime}$ latitud norte, y entre $99^{\circ} 42^{\prime}$ $59^{\prime \prime}$ y $100^{\circ} 23^{\prime} 38^{\prime \prime}$ longitud oeste. El clima predomínate es templado subhúmedo frío $\mathrm{Cb}(\mathrm{w} 1)\left(\mathrm{i}^{\prime}\right) \mathrm{w}$ ", con lluvias en verano, una precipitación promedio anual de $600-800 \mathrm{~mm}$ y una temperatura media de $12-18{ }^{\circ} \mathrm{C}$ (Medina García et al., 1998). Un aspecto característico del área de estudio son las serranías bajas (500-700 msnm) y los picos montañosos (>1 $500 \mathrm{msnm}$ ). Los suelos están constituidos por varias asociaciones de regosol calcárico, feozem calcárico, rendzina con luvisol crómico y también, suelos de castañozem cálcico en fase lítica, en donde la vegetación característica es de tipo bosques de encino, encino-pino y Juniperus (SPP, 1981).

Las poblaciones silvestres fueron recolectadas durante el período 2010-2012, en dos exploraciones por año, una en agosto y septiembre, cuando las plantas se encontraban en las etapas vegetativa-floración, y otra en octubre, noviembre y diciembre, cuando las plantas se encontraban en madurez fisiológica. En la etapa vegetativa-floración se recolectaron muestras de herbario, principalmente tallos, hojas y flores. En madurez fisiológica se recolectaron muestras de semillas.

La identificación de las especies se realizó con base en los tratados taxonómicos de Delgado-Salinas (1985) y Freytag y Debouck(2002). Las muestras fueronalmacenadas en frascos de vidrio, cerrados y etiquetados, con una humedad del grano inferior al 15\%, y enviadas al banco de germoplasma de semillas de la Universidad Autónoma AgrariaAntonio Narro (UAAAN), para su conservación ex situ.

Se determinaron 54 sitios con presencia de una o más especies, en donde se recolectaron muestras de semilla y se identificaron siete especies de Phaseolus. La distribución de especies silvestres en Nuevo León ha estado restringida en las estribaciones montañosas de la región de la Sierra Madre Oriental de México, en los municipios de San Pedro, Monterrey, Santiago, Allende, Montemorelos, Rayones, Linares, Galeana, Iturbide, Aramberri, Zaragoza y Dr. Arroyo (Cuadro 1), en donde la mayor diversidad se
The collection was carried out in 12 municipalities of the state of Nuevo León with significant records in Phaseolus wild species diversity in the Sierra Madre Oriental region of Mexico, geographically located between $23^{\circ} 56^{\prime} 23^{\prime \prime}$ and $25^{\circ} 42^{\prime} 59^{\prime \prime}$ north latitude and between $99^{\circ} 42^{\prime} 59^{\prime \prime}$ and $100^{\circ} 23^{\prime} 38^{\prime \prime}$ west longitude. The predominant climate is cold sub-humid temperate $\mathrm{Cb}(\mathrm{w} 1)\left(\mathrm{i}^{\prime}\right) \mathrm{w}$ ", with summer rains, an average annual rainfall of $600-800 \mathrm{~mm}$ and an average temperature of $12-18{ }^{\circ} \mathrm{C}$ (Medina García et al., 1998). A characteristic feature of the study area the low hills (500-700 $\mathrm{m}$ ) and the mountain peaks (>1500 masl). Soils are composed of several associations of calcaric regosol, calcaric phaeozem rendzina with chromic luvisol and calcic kastanozem in lytic phase, where the vegetation type is oak forests, oak-pine and Juniperus (SPP, 1981).

Wild populations were collected during the period 20102012, in two explorations per year, one in August and September, when plants were in the vegetative-flowering stages, and another in October, November and December, when plants were at physiological maturity. In the vegetativeflowering stage, herbarium specimens, mainly stems, leaves and flowers were collected. At physiological maturity, seed samples were collected.

The species identification was done based on the taxonomic treatises of Delgado-Salinas (1985) and Freytag and Debouck (2002). Samples were stored in glass jars, sealed and labeled, with less than $15 \%$ grain moisture, and sent to the germplasm bank of the Antonio Narro Autonomous Agricultural University (UAAAN), for ex situ conservation.

Overall 54 sites were determined with one or more species present, where seed samples were collected and seven Phaseolus species were identified. The distribution of wild species in Nuevo León has been restricted in the foothills of the Sierra Madre Oriental region of Mexico, in the San Pedro, Monterrey, Santiago, Allende, Montemorelos, Rayones, Linares, Galeana, Iturbide, Aramberri, Zaragoza and Dr. Arroyo municipalities (Table 1), where the greatest diversity has been found in Aramberri (five species), Rayones (four species), Santiago, Montemorelos and Zaragoza (three species).

Among the species of greater incidence and distribution, $P$. neglectus (24 collections), P. leptostachyus (15 collections) and $P$. pedicellatus (eight collections) stand out; also $P$. albiflorus, $P$. novoleonensis and $P$. maculatifolius were 
ha encontrado en Aramberri (cinco especies), Rayones (cuatro especies), Santiago, Montemorelos y Zaragoza (tres especies). important with two collections, respectively, in contrast, $P$. zimapanensis is a taxon with very limited distribution, only collected at a single site in the Lampacitos town

Cuadro 1. Recolectas de especies silvestres obtenidas en el período 2010-2012, en 12 municipios del estado de Nuevo León, México. Table 1. Collections of wild species obtained in the period 2010-2012, in 12 municipalities of the state of Nuevo León, Mexico.

\begin{tabular}{|c|c|c|c|c|c|c|c|}
\hline Municipio & $(1)^{*}$ & (2) & (3) & (4) & (5) & (6) & (7) \\
\hline San Pedro & 1 & & & & & & \\
\hline Monterrey & 2 & & & & & & \\
\hline Santiago & 6 & 4 & & 1 & & & \\
\hline Allende & 2 & & & & & & \\
\hline Rayones & 3 & 2 & & 1 & 2 & & \\
\hline Montemorelos & 2 & 1 & & & & 1 & \\
\hline Linares & 2 & 2 & & & & & \\
\hline Iturbide & 2 & & & & & & \\
\hline Galeana & & & 3 & & & & \\
\hline Aramberri & 2 & 4 & 2 & & & 1 & 1 \\
\hline Zaragoza & 2 & 1 & 2 & & & & \\
\hline Dr. Arroyo & & & 1 & & & & \\
\hline Total & 24 & 15 & 8 & 2 & 2 & 2 & 1 \\
\hline
\end{tabular}

Entre las especies de mayor presencia y distribución, destacaron P. neglectus (24 recolectas), P. leptostachyus (15 recolectas) y P. pedicellatus (ocho recolectas); también $P$. albiflorus, $P$. novoleonensis y $P$. maculatifolius fueron importantes con dos recolectas, respectivamente; en contraste, $P$. zimapanensis es un taxón con distribución muy limitada, ya que solamente se recolectó en un sitio en la localidad de Lampacitos del municipio de Aramberri. Es importante señalar que en el presente trabajo, no se encontraron sitios con presencia de $P$. grayanus, $P$. altimontanus y $P$. polymorphus, taxones previamente reportados en Nuevo León (Rodríguez Cabrera et al., 1985; Freytag y Debouck, 2002; Estrada Castillón et al., 2004).

En lo que respecta a la altitud y especies encontradas en el presente trabajo, se podría señalar que $P$. neglectus tuvo la mayor área de distribución, encontrándose desde los 2170 msnm en la parte alta en el municipio de Zaragoza, hasta los 665 msnm en el municipio de Santiago (Cuadro 2).

En segundo lugar estuvo P. leptostachyus, recolectada desde los 1990 msnm en el municipio de Santiago, hasta los 714 msnm en el municipio de Monterrey (Cuadro 2). Esta especie se observó con alguna frecuencia en las partes intermedias y altas de la región de la Sierra Madre Oriental de México, principalmente en ambientes abiertos de vegetación arbórea, entre bosques de pino y encino, ya que es una especie de of the Aramberri municipality. Importantly, in this study, no sites were found with presence of $P$. grayanus, $P$. altimontanus and $P$. polymorphus, previously reported taxa in Nuevo León (Rodríguez Cabrera et al., 1985; Freytag and Debouck, 2002; Estrada Castillón et al., 2004).

With respect to altitude and species found in this study, it could be noted that $P$. neglectus had the highest range, found from the 2170 masl at the top of the Zaragoza municipality, up to 665 masl in the Santiago municipality (Table 2).

P. leptostachyus was the second, collected from 1990 masl in the Santiago municipality, to 714 masl in the Monterrey municipality (Table 2). This species was observed with some frequency in the middle and upper parts of the Sierra Madre Oriental region of Mexico, mainly in open environments with trees, between pine and oak forests, as it is a species with indeterminate growth of creeping type, thriving well in disturbed sites but protected from factors representing threats to its growth and development. These results agree with those obtained by Lépiz et al. (2004a and 2004b) in the region of the Verde and Santiago rivers in the state of Nayarit.

P. pedicellatus ranked third, found from the 2820 masl on the slopes of Cerro del Potosí in the Galeana municipality, up to 1990 masl in the Agua Fria town of 
crecimiento indeterminado tipo rastrero, que próspera bien en sitios perturbados pero que estén protegidos de factores que representen amenazas para su crecimiento y desarrollo. Estos resultados concuerdan con los obtenidos por Lépiz et al. (2004a y 2004b) en la región de los ríos Verde y Santiago en el estado de Nayarit. the Aramberri municipality (Table 2). This species is located at higher altitude sites, where wild bean was found and grew up in damp and shade in the oak and pine forest. Similar results have been reported by Lépiz et al. (2004a and 2004b) in the slopes of the Nevado de Colima.

Cuadro 2. Características de especies silvestres obtenidas en el período 2010-2012, en el estado de Nuevo León, México. Table 2. Characteristics of wild species obtained in the period 2010-2012, in the state of Nuevo León, Mexico.

\begin{tabular}{lccccc}
\hline Especie & $\begin{array}{c}\text { Núm. de } \\
\text { semillas / vaina }\end{array}$ & $\begin{array}{c}\text { Peso de 100 } \\
\text { semillas (g) }\end{array}$ & $\begin{array}{c}\text { Tipo de } \\
\text { crecimiento }\end{array}$ & $\begin{array}{c}\text { Color } \\
\text { de flor }\end{array}$ & $\begin{array}{c}\text { Altitud } \\
(\mathrm{msnm})\end{array}$ \\
\hline P. neglectus & $5-8$ & $4.07-5.3$ & Trepador & Blanca & $665-2170$ \\
P. leptostachyus & $3-5$ & $1.5-1.8$ & Rastrero & Lila & $714-1990$ \\
P. pedicellatus & $3-4$ & $7.2-8.5$ & Trepador & Lila fuerte & $1990-2820$ \\
P. albiflorus & 5 & $4.4-4.5$ & Rastrero & Blanca, estandarte con tono lila & $1061-1555$ \\
P. novoleonensis & 3 & 10.8 & Rastrero & Lila fuerte & $1150-1291$ \\
P. maculatifolius & 4 & 7.9 & Trepador & Lila & $1136-1836$ \\
P. zimapanensis & 6 & $1.7-1.9$ & Trepador & Lila & 1210 \\
\hline
\end{tabular}

Eltercerlugar lecorrespondióaP.pedicellatus, encontrándose desde los 2820 msnm en las faldas del Cerro del Potosí en el municipio de Galeana, hasta los 1990 msnm en la localidad deAgua Fría en el municipio de Aramberri(Cuadro 2). Ésta especie se localizó en los sitios de mayor altitud, en donde se encontró frijol silvestre; creció en ambientes húmedos y de sombra, en el bosque de encino y pino. Resultados similares han sido reportados por Lépiz et al. (2004a y 2004b) en la región de las faldas del Nevado de Colima.

La cantidad de formas silvestres de Phaseolus recolectada en Nuevo León, todavía no está completa de acuerdo con los con los resultados obtenidos previamente (Rodríguez Cabrera et al., 1985; Freytag y Debouck, 2002; Estrada Castillón et al., 2004) y menos aún evaluada. Asimismo, las 10 especies de Phaseolus reportadas para Nuevo León se podrían considerar bajo en comparación con la diversidad genética consignada en otros estados como Jalisco, Durango, Oaxaca y Chiapas (Delgado-Salinas, 2012).

Las especies de Phaseolus reportadas en el presente estudio son de ciclo perenne y de hábito de crecimiento indeterminado, cuatro son trepadoras (P. neglectus, $P$. pedicellatus $P$. maculatifolius y $P$. zimapanensis) y tres rastreras ( $P$. leptostachyus, $P$. novoleonensis y $P$. albiflorus) (Cuadro 2). El ciclo perenne estuvo relacionado con el engrosamiento del sistema radical, característica morfológica que permite que las plantas tengan la capacidad
The amount of wild forms of Phaseolus collected in Nuevo León, is still incomplete according to previous results (Rodríguez Cabrera et al., 1985; Freytag and Debouck, 2002; Estrada Castillón et al., 2004) and yet less evaluated.In addition, the 10 Phaseolus species reported for Nuevo León could be considered low compared to the genetic diversity contained in other states such as Jalisco, Durango, Oaxaca and Chiapas (Delgado-Salinas, 2012).

Phaseolus species reported in this study exhibit perennial cycle and indeterminate growth habit, four are climbing (P. neglectus, $P$. pedicellatus $P$. maculatifolius and $P$. zimapanensis) and three creeping ( $P$. leptostachyus, $P$. novoleonensis and $P$. albiflorus) (Table 2 ). The perennial cycle was associated with thickening of the root system, a morphological feature conferring plants the ability to reproduce vegetatively, since it has been observed that growth reaches about $40 \mathrm{~cm}$ or more in length. Overall wild beans showed fibrous or fleshy roots, sometimes the size of a yam bean, from whose crowns herbaceous or sometimes somewhat woody stems developed (Delgado Salinas, 2012).

In Nuevo León, wild species of the genus Phaseolus have been seriously affected by the historical exploitation of cattle and goats, which has been indiscriminately managed on mountain pastures, causing great damage to the native flora; another adverse factor has been the road maintenance 
de reproducirse en forma vegetativa, ya que se ha observado que llega a crecer alrededor de $40 \mathrm{~cm}$ o más de longitud. En general los frijoles silvestres presentaron raíces fibrosas o carnosas, a veces de dimensiones como la jícama, desde cuyas coronas se desarrollaron tallos herbáceos o a veces algo leñosos (Delgado Salinas, 2012).

En Nuevo León, las especies silvestres del género Phaseolus han sido seriamente afectadas por el impulso histórico a la explotación de ganado vacuno y caprino, el cual se ha maneja indiscriminadamente en potreros serranos, causando un gran daño a la flora nativa; otro factor adverso ha sido el mantenimiento de las vías de comunicación por parte de las juntas locales de caminos, como fue el caso de dos poblaciones pequeñas de $P$. novoleonensis encontradas en la cuneta de la carretera entre los municipios de Allende y Rayones. Adicionalmente, las poblaciones silvestres de frijol han sido afectadas por otros factores, tales como el cambio climático, la destrucción de los ambientes naturales, aumento de tierras al cultivo, incremento de la ganadería y la agricultura intensiva, causas que trajeron consigo la pérdida de estas poblaciones (Brush, 2000; Acosta-Gallegos, 2012).

\section{Conclusiones}

Se recolectaron 54 muestras de semillas de poblaciones silvestres de Phaseolus en 12 municipios del estado de Nuevo León en la región del Sierra Madre Oriental. La diversidad genética observada estuvo representada por siete especies (P. neglectus, P. leptostachyus, $P$. pedicellatus, $P$. novoleonensis, $P$. albiflorus y $P$. zimapanensis). Es posible que se haya perdido germoplasma, por lo que se hace necesario continuar explorando y recolectando otras poblaciones silvestres en Nuevo León. Es necesario iniciar trabajos de recolección de germoplasma de poblaciones silvestres de frijol en los estados de Tamaulipas y Coahuila.

\section{Agradecimientos}

Al Sistema Nacional de Inspección y Certificación de Semillas (SNICS), que a través del Sistema de Recursos Fitogenéticos para la Alimentación y la Agricultura (SINAREFI), financió el proyecto: "Colecta de semillas de especies silvestres de frijol en Nuevo León, México". by local boards of roads, as the case of two small populations of $P$. novoleonensis found by the roadside between the Allende and Rayones municipalities. Additionally, wild bean populations have been affected by other factors, such as climate change, destruction of natural environments, expanding cultivation lands, increased livestock and intensive agriculture which caused the loss of these populations (Brush, 2000; Acosta-Gallegos, 2012).

\section{Conclusions}

Overall 54 seed samples of wild populations of Phaseolus were collected in 12 municipalities of the state of Nuevo León in the Sierra Madre Oriental region. The observed genetic diversity was represented by seven species (P. neglectus, $P$. leptostachyus, P. pedicellatus, P.novoleonensis, P.albiflorus and $P$. zimapanensis). Some germplasm maybe missing, therefore there is a need to continue exploring and collecting other wild populations in Nuevo León. Also germplasm collection of wild bean populations is required in the states of Tamaulipas and Coahuila.

End of the English version

\section{Literatura citada}

Acosta-Gallegos, J. A.; Muruaga-Martínez, J. S.; Cárdenas Ramos, F. y Khairallah, M. M. 1996. Estrategias para la utilización de germoplasma de Phaseolus en el mejoramiento genético. Ciencia. 47:149-160.

Acosta-Gallegos, J. A.; Mendoza-Hernández, F. M.; Mora-Avilés, A.; Muruaga-Martínez, J. S.; Paredes-López, O. y Valverde, M. E. 2007. Rescate, regeneración y caracterización de Phaseolus spp. (Fabaceae) y P. vulgaris en México. In: Lépiz, I. (Ed.) Avances de investigación 2003-2006. Red Frijol. SAGARPA, SINAREFI. Guadalajara, Jalisco. 72-81 pp.

Acosta-Gallegos, J. A. 2012. Los frijoles silvestres Phaseolus spp. en el estado de Guanajuato. In: La biodiversidad en Guanajuato: estudio de estado. Comisión Nacional para el Conocimiento y Uso de la Biodiversidad (CONABIO)- Instituto de Ecología del estado de Guanajuato (IEE). 2:350-353.

Brush, S. B. 2000. Genes in the field. On-farm conservation of crop diversity. Rome, Italy. International Plant Genetic Resources Institute and International Development Research Center. $288 \mathrm{p}$.

Cárdenas-Ramos, F.; Muruaga-Martínez, J. S. y Acosta-Gallegos, J. A. 1996. Catálogo del Banco de Germoplasma de Phaseolus del INIFAP. México. 421 p. 
Delgado-Salinas, A. O. 1985. Systematics of the genus Phaseolus (Leguminoseae) in North and Central America, Ph. D. Thesis University of Texas-Austin. $240 \mathrm{p}$.

Delgado Salinas, A. O; Bonet, A. and Gepts, P. 1988. The wild relative of Phaseolus vulgaris in Middle America. In: P. Gepts (ed.) Genetic resources in Phaseolus beans. Kluwer Academic Publishers. 163-184 pp.

Delgado-Salinas, A. O.; Turley, T.; Richman, A. and Lavin, M. 1999. Phylogenetic analysis of the cultivated and wild species of Phaseolus (Fabaceae). Syst. Bot. 24:438-460.

Delgado-Salinas, A. O.; Bibler, R. and Lavin, M. 2006. Phylogeny of the genus Phaseolus (Leguminosae): Arecent diversification in an ancient landscape. Syst. Bot. 31:779-791.

Delgado-Salinas,A. O. 2012. La historia natural del frijol(Phaseolus).In: el frijol. Un regalo de México al mundo. Fundación Herdez. www. fundacionherdez.com.mx. (consultado julio, 2013). 17-18 pp.

Estrada Castillón, A. E.; Yen, M. C.; Delgado Salinas, A. O. y Villareal Q. J. A. 2004. Leguminosas del centro del estado de Nuevo León, México. Anales del Instituto de Biología, UNAM. Serie Botánica 75:73-85.

Freytag, G. F. and Debouck, D. G. 2002. Taxonomy, distribution and ecology of the genus Phaseolus (Leguminosae-Papilionoideae) in North America, Mexico and Central America. SIDA Bot. Misc. 23:1-300.

Gepts, P.; Osborn, T. C.; Rashka, K. and Bliss, F. A. 1986. Phaseolinprotein variability in wild forms and landraces of the common bean (Phaseolus vulgaris): evidence for multiple centers of domestication. Econ. Bot. 40:451-468.

Gepts, P. and Debouck, D. G. 1991. Origen. Domestication and evolution of the common bean (Phaseolus vulgaris L.). In: Schoonhoven, A. Van and Voyset, O. (Eds.). Common bean research for crop improvement. CAB. International. 7-53 p.
Lépiz I. R.; Ramírez, D. R. R.; Sánchez, G. J.A.; Ruíz, C. J.A. y Debouck, G. D. 2004a. Variabilidad fenotípica en Phaseolus vulgaris L. silvestre en el Occidente de México. In: Memoria XX Congreso Nacional de Fitogenética. Toluca, Estado de México. 19-24 de septiembre de 2004. 199 p.

Lépiz I. R.; Ramírez, D. R. R.; Sánchez, G. J. A.; Ruíz, C. J. A. y Debouck, G. D. 2004b. Las especies silvestres de Phaseolus L. (Fabaceae) en la cuenca de los ríos Verde y Santiago y Nevado de Colima, del Occidente de México. ScientiaCUCBA. 6(1-2):91-99.

McVaugh, R. 1987. Flora Novo Galicia. A descriptive account of the vascular plants of Western Mexico. Volume 5. Leguminosae. The University of Michigan Press. 786 p.

Medina- García, G.; Ruiz, C. J. A. y Martínez, P. R. A. 1998 Los climas de México: una estratificación ambiental basada en el componente climático. Libro técnico Núm. 1. INIFAPCIRPAC. Ed. Conexión Gráfica. Guadalajara, Jalisco. México. 103 p.

Peña Valdivia, C. B.; Aguirre Rivera, J. R. y Arroyo Peña, V. B. 2012. El frijol silvestre. Síndrome de domesticación. Libro. Colegio de Postgraduados en Ciencias Agrícolas. Montecillo, Texcoco, Estado de México. México. 206 p.

Rodríguez-Cabrera, H.; Rodríguez-Tijerina, S.; Aguilar-Sanmiguel, M. and Debouck, D. G. 1985. Phaseolus germoplasm collection in México. Plant Genetic Res. Newsletter. 69:30-38.

Salcedo, C. J.; Arroyave, J. A.; Toro, Ch. O. and Debouck, G. D. 2006. Phaseolus novoleonensis, a new species (Leguminosae, Phseolinae) from the Sierra Madre Oriental, Nuevo León, México. Novon 16:105-111.

Secretaría de Programación y Presupuesto (SPP). 1981. Síntesis geográfica del estado de Nuevo León. México D. F. 170 p. + 13 mapas. 